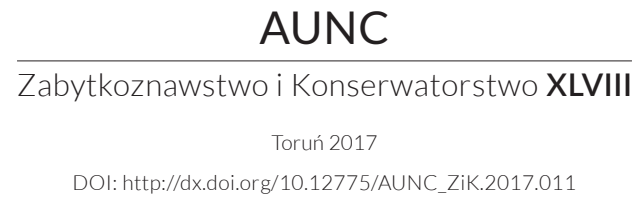

\title{
Selected aspects of painting technique of Alfred Wierusz-Kowalski
}

\author{
ELŻBIETA BASIUL \\ Department of Technology and Painting Techniques, \\ Faculty of Fine Arts, Nicolaus Copernicus University in Toruń \\ e-mail: Elzbieta.Basiul@umk.pl \\ MAGDALENA SITKIEWICZ \\ Department of Technology and Painting Techniques, \\ Faculty of Fine Arts, Nicolaus Copernicus University in Toruń \\ e-mail: m.sitkiewicz@umk.pl
}

Key words: Alfred Wierusz-Kowalski, painted sketch, painting technique, academic painting, esquisse, ébouche

Słowa kluczowe: Alfred Wierusz-Kowalski, szkic malarski, technika malarska, malarstwo akademickie, esquisse, ébouche.

\begin{abstract}
On the basis of the aforementioned analysis, it can be stated that Wierusz-Kowalski did not adhere to rigorous academic schemes. The path of his artistic development and the decisions he made as a result of his progress indicate that only as a young artist he was very much aware of what kind of creator he wanted to be and realized the most essential elements in his view of the world and art. It should be emphasized that the teachers, or rather the guides in the world of art, under the tutelage of whom he developed his skills did not try to influence the form and character of his work. The analysis of the works of Wierusz-Kowalski shows that the realistic convention of presenting the world there remained basically unchanged. However, in terms of painting techniques themselves, one can see the influence of the new trends emerging in the
\end{abstract}


last quarter of the nineteenth century. It is visible in the area of the artistic means of expression and workshop methods, which the painter freely changed and individually developed. Wierusz-Kowalski fully enjoyed artistic freedom that was increasingly guaranteed by the Academy at that time. His sketches and expressive images referred to French and Belgian paintings, which placed a sensitive observation of nature above a long-term painting process in the studio. The supporters of this type of art were constantly on the rise, because the "first impression" and individuality of the creator were more and more appreciated. Expressive paintings and sketches became to be treated as finite works. A look at the artistic heritage of Wierusz-Kowalski from the perspective of contemporary changes in art and artistic approaches allows for a more complete assessment of the painter's output. From this point of view, the artist appears as a very sensitive and immensely talented creator, who expressed himself in numerous painted sketches and every so often was hidden behind academically accurate picture as well as completed works marked with considerable artistic autonomy.

\section{Abstrakt}

„Ekspresja w okowach akademizmu. Wybrane aspekty warsztatu malarskiego Alfreda Wierusza Kowalskiego”

Niniejszy artykuł dotyczy techniki malarskiej wybranych dzieł Alfreda Wierusza-Kowalskiego, pochodzących z kolekcji Muzeum Okręgowego w Suwałkach, Muzeum Sztuki w Łodzi oraz z kolekcji prywatnych. Warsztat tego artysty, obok wartości stylowych i tematycznych, jest uważany za przykład warsztatu typowego dla XIX-wiecznego akademizmu. Całościowe spojrzenie na dorobek A. Wierusza-Kowalskiego wskazuje na istotną w nim rolę szkiców malarskich, jako dzieł samodzielnych oraz ekspresyjnych faz wstępnych w obrazach opracowanych w końcowych etapach zgodnie z regułą akademicką. W jego malarstwie odnaleźć można symptomy nowych tendencji warsztatowych, które pojawiły się w malarstwie 2 poł. XIX i na początku XX wieku.

\section{Introduction}

This paper concerns painting workshop of Alfred Wierusz-Kowalski ${ }^{1}$, who is believed to have been a typical representative of the $19^{\text {th }}$ century academism. The information presented herein resulted from preliminary research on the

1 Preliminary study of the subject was presented by Elżbieta Basiul end Magdalena Sitkiewicz during the academic session organized in the Muzeum Okręgowe w Suwałkach [Regional Museum in Suwałki] and entitled "Jakie tajemnice kryją obrazy monachijczyków? Kilka nowych spostrzeżeń na temat warsztatu malarskiego Alfreda Wierusza-Kowalskiego" (academic session „Egzotyczna Europa. Malarstwo monachijskie 1870-1914”. Suwałki, 5-6th October, 2015). For more information about the technological and technical issues of selected sketches done by the artist see: Sylwia Ziemlewicz, „Technika i technologia szkicu malarskiego Alfreda Wierusza-Kowalskiego pt. 'Przed burzą’ pochodzącego z Muzeum Okręgowego w Suwałkach” (M.A. thesis, Nicolaus Copernicus University in Toruń, 2013). 
artist's workshop and was based on the analysis of certain paintings from the Regional Museum in Suwałki. A complete look at the artistic output of Wierusz-Kowalski indicates that painted sketches were of much importance for him as self-sufficient and expressive preliminary studies of the paintings completed in accordance with the academic rule. The oil sketches, which any student was preparing throughout their education to perform the final painting at the academy, were presented at the very first stage of the annual competition Prix the Rome. They found themselves in the centre of a struggle between the academics and the proponents of certain innovative tendencies, which appeared in art in the $19^{\text {th }}$ century. A painted sketch treated equally with a complete painting was seen as a gateway from the rigid academic rules, which made it possible to emphasize uniqueness and spontaneity of the creative process ${ }^{2}$.

\section{At the Munich Academy}

Alfred Wierusz-Kowalski was a painter who developed his artistic and technical skills first in Poland, then in Dresden, Prague and finally in Munich. In the nineteenth and early twentieth century, Munich was one of the most significant artistic centers in Europe. In that term, it was compared to Paris. What was attracting young artists was the opportunity to acquire or improve their education in the Royal Academy of Fine Arts since 1808 as well as in numerous private painting schools $\mathrm{s}^{3}$. The nineteenth century curriculum of the Munich Academy was not far from the educational systems of other academies of that time. The academies allowed their students to obtain technical skills. Regardless of the direction in which the artists developed in the further stages of their careers, a faultless workshop drilled at the academy was clearly noticeable 4 . Wierusz-Kowalski appeared in Munich in the 1970s. At that time, the main idea of the Academy as well as its curriculum were

2 Maria Poprzęcka, Akademizm (Warszawa: WAiF, 1980), 76-79. For more information about the academic sketches see: Albert Boime, The Academy and French Painting in the Nineteenth Century (London: Phaidon, 1971), 79-101 and indicated literature.

3 Andrzej Holeczko-Kiehl, introduction to Brandt... Malczewski... Siemiradzki...: polscy monachijczycy, malarze polscy w kręgu Akademii Sztuk Pięknych w Monachium 1828-1914. Wystawa malarstwa ze zbiorów Lwowskiej Galerii Sztuki we Lwowie (Katowice: Muzeum Śląskie, 2005-2006), 6; Andrzej Holeczko-Kiehl, „Wierni miłości do ojczyzny. Artyści polscy w kręgu Monachium", in Brandt... Malczewski..., 22.

4 Halina Stępień, Artyści polscy w środowisku monachijskim 1856-1914 (Warszawa: Instytut Sztuki PAN, 2003), 53. 
transformed. The community of Munich School began to appreciate individualism in art. It was there where an artist was seen as a genius and where the slogan "art for the art" was proclaimed, on the basis of which there was promoted the equality of directions, tendencies and styles in $\operatorname{art}^{5}$. The educational system proposed by the Academy started with the classes of drawing from ancient sculptures, followed by classes of drawing from a living model, then classes of painting techniques, and finally classes of composition, so-called "master classes". The structure and organization of the Academy remained conservative for a long time. Yet, mainly from the 1870s, it offered a great deal of freedom to the artists studying there. Many artists sought to become independent as quickly as possible; thus, they used the educational offer of the Academy in a selective way ${ }^{6}$. This was also the path chosen by A. Wierusz-Kowalski, who spent only a few months in the Academy, attending the workshop of Alexander Wagner ${ }^{7}$, a painter praised by many Polish artists. It is known that he painted a lot at that time, creating independent and thoughtful compositions, not academic studies or practical exercises. As short as in the class conducted by A. Wagner, the artist studied in the private studio of Józef Brandt ${ }^{8}$. When Wierusz-Kowalski came to Munich, he was

5 Birgit Jooss, „Akademia Sztuk Pięknych w Monachium”, in Malarze polscy w Monachium. Studia i szkice. Materiały z sesji naukowej, ed. Zbigniew Fałtynowicz and Eliza Ptaszyńska (Suwałki: Muzeum Okręgowe, 2007), 15; Holeczko-Kiehl, „Wierni miłości”, 22-23.

6 Eliza Ptaszyńska, Alfred Wierusz-Kowalski 1849-1915 (Warszawa: Wydawnictwo DiG, 2011), 67-72 and indicated literature. More on a way and character of educating students at the Academy as well as dynamic changes in the structure of the school in the 19th century see: Birgit Jooss, „Między studium antyków a klasą mistrzowską. Codzienne zajęcia w monachijskiej akademii sztuki w XIX wieku”, trans. by Marcin Pastwa, in Ateny nad Izara. Malarstwo monachijskie. Studia i szkice, ed. Eliza Ptaszyńska (Suwałki: Muzeum Okręgowe, 2012), 17-37.

7 Ptaszyńska, Alfred Wierusz-Kowalski, 67, 69 and indicated literature. It is pointed out in the literature that A. Wagner taught about the possible means of artistic expression, but as an educator he did not influence much the painters who he was supervising neither with his personality nor his artistic style. Thus, he let them freely develop. This is proved by divergent artistic styles presented by his students. See e.g. Tadeusz Jaroszyński, „Obrazy Wagnera oraz jego uczni Polaków”, Tygodnik Ilustrowany 21 (1906): 408. 26.05.1906; Władysław Wankie, „Aleksander Wagner i jego polscy uczniowie”, Świat 24 (1906): 11. 16.06.1906.

8 Letters from Wierusz-Kowalski to Brandt indicate that the artist - despite short period of time that he spent under the eye of Brandt - even at the end of his life still claimed to have been his student. A letter of Alfred Wierusz-Kowalski to Józef Brandt from the $9^{\text {th }}$ of June, 1908, Munich, the District Museum of Jacek Malczewski, Radom. The letter published in a booklet of the exhibition entitled Józef Brandt - pracownia artysty, ed. Zbigniew Fałtynowicz (Suwałki: Muzeum Okręgowe, 2000). Ptaszyńska, Alfred Wierusz-Kowalski, 80, 238-239 and indicated literature. Wierusz-Kowalski was in close touch with Józef Brandt and a group of Polish artists staying in a narrow circle of this artist. Literature indicates that Brandt 
already a solidly-formed artist, with excellent workshop foundations, developed primarily during his earlier education at Wojciech Gerson's private studio ${ }^{9}$. Probably for that reason he was immediately qualified at the Academy to attend the painting class ${ }^{10}$.

\section{Academic and traditionalist}

Alfred Wierusz-Kowalski was firmly rooted in the $19^{\text {th }}$ century traditional academic painting. He never steered away from the realistic convention, which was created by the cube, depth and movement and where the idea of the picture was seen as a "window to the world". Formal means applied by the artist together with the colours, idea and themes of the painting did not change a lot even at the end of his artistic career ${ }^{11}$. He used a variety of props, garments and jewelry collected in the studio as well as the photographs depicting e.g. posing models ${ }^{12}$. He also made use of outdoor sketches,

inspired Wierusz-Kowalski in terms of the mood of depicting winter landscapes, methods of showing people in the portraits and animals from a close perspective, using changes of a character's motion vector and foreshortenings, which tightened the relation between spectator and painting. Hans-Peter Buhler, Józef Brandt, Alfred Wierusz-Kowalski i inni. Polska szkoła monachijska, transl. by Tomasz Kozłowski (Warszawa: Amber, 1997), 25-26, 36, $54-55,116$.

9 Wierusz-Kowalski learnt in the private studio of W. Gerson from 1868. At the same time he attended the classes in Warsaw School of Drawing, where he was tutored by Rafał Hadziewicz and Aleksander Kamiński. Ptaszyńska emphasizes that it was especially Gerson, who influenced Wierusz-Kowalski in terms of quality and level of artistic skills at the early stage of his education. Ptaszyńska, Alfred Wierusz-Kowalski, 220-221. Profound engagement of Gerson in the process of education was appreciated by his students. He paid a lot of attention to the individual development of each student and encouraged them to listening to themselves during the process of creation. At the same time, he advised not to use the ideas or artistic means of expression taken from the other artists. While correcting his students' works, Gerson tried not to suppress them with his own views or technical solutions. The fact that his students enjoyed the freedom of expression is proved by the words of Gerson himself, which reflected his pedagogical ideas: „Let a student know less, but let it be his own skill. Let him get used to going into his own entity, researching his own personality and preferences. Let him see in a surrounding, wealthy nature, which is unlimited source of artistic inspirations a new material, the most appropriate for himself. Let him be himself without following anybody”. Feliks Słupski, „Wojciech Gerson. Artysta, nauczyciel, człowiek”, in Wojciech Gerson i jego uczniowie, Przewodnik 65: lato 1931 roku. Towarzystwo Zachęty Sztuk Pięknych w Warszawie (Warszawa: Druk M. Garasiński, 1931), 8, 11; Jan Kleczyński, „Uczniowie Gersona”, in Wojciech Gerson, 16-17, 20.

10 Ptaszyńska, Alfred Wierusz-Kowalski, 67-69 and indicated literature.

11 Ptaszyńska, Alfred Wierusz-Kowalski, 270-271.

12 A. Wierusz-Kowalski collected in his studio a great number of the photos that he took either in his studio or outside. They showed models, carefully posed by the artist. The scenes de- 
which were specific notes taken during his journeys ${ }^{13}$. It was similar in case of preparation and performing a painting according to academic convention. At its initial stage, it assumed a miniature sketch drawn out of imagination, a record of a "first thought", which was a draft of the final work. It was done quickly, usually on paper; in pencil, charcoal or ink. Next stage, made on a separate support, was to transfer a drawing of a composition to the support and perform a quick drawing up, on the surface of which the painting was finished. At this stage, there were most frequently used the rules referring to the painting palette limited mainly to earth pigments; technique and sequence in which the lights and shadows of a particular scene were developed. Prior to the final version of the painting, the artist usually performed a number of neatly sketched or painted pieces of a certain composition ${ }^{14}$. Drawings and painted works presented at the Muzeum Okręgowe [Regional Museum] in Suwałki prove that Wierusz-Kowalski was under the influence of academism. It is shown in a sketch of a large-scale picture entitled Napad wilków ["Wolves

picted in those pictures were very often cautiously reflected in the canvas. The painter supported himself also with the pictures which he got from his friends. In his work, he used many accessories, such as: armor, harness and horse decorations, elements of folk clothes, women, men and children's outfits, from the hats to the shoes from different parts of the world. It is indicated in the literature that he also applied the themes and props that he saw in the studios or collections of the other artists (e.g. the collection of a late artist Theodor Horachelter, which Wierusz-Kowalski came across in the studio of J. Brandt and the motifs of which he used in his works concentrated on the subject of Caucasus). Ptaszyńska, Alfred Wierusz-Kowalski, 106-107, 109-112, 198-199 and indicated literature.

13 The sketches made during his trip to North Africa, Wierusz-Kowalski then applied in the oriental scenes. Anna Dajnowska, „Alfred Wierusz-Kowalski w świetle opinii polskiej krytyki artystycznej w latach 1870-1915”, in O Alfredzie Wieruszu-Kowalskim. Studia, szkice, wspomnienia, Materiały z sesji popularnonaukowej w 150-lecie urodzin Artysty, Suwałki, 11 października 1999, ed. Zbigniew Fałtynowicz and Zygmunt Filipowicz (Suwałki: Stowarzyszenie Przyjaciół Suwalszczyzny, 2000), 47 and indicated literature.

14 It can be pointed out that at the French Academy, each drawing and painting stage of the student's work had its own name, e.g. croquis (a miniature sketch from the imagination), esquisse (a painting sketch on a separate canvas), ébauche (a painting developed on the right support, where the painting was finished), étude (studies from the nature of selected fragments of the composition), fini (precise completion of the painting work). Boime, The Academy, 34-37, 81 and indicated literature; Techniki wielkich mistrzów malarstwa, co-writers David A. Anfam et al., transl. by Dorota Stefańska-Szewczuk, Monika Dolińska, and Bożena Mierzejewska (Warszawa: Arkady, 2006), 108-109; Virgil Elliott, Traditional Oil Painting. Advanced Techniques and Concepts from the Renaissance to the Present (New York: Watson-Guptill Publications, 2007), 103. On the issue of similarities in artistic education in European art centers in the 19th century see: Władysław Ślesiński, „O sytuacji w zakresie technologii i technik malarskich w dobie romantyzmu”, Ochrona Zabytków 19, no. 3 (1966): 14 and indicated literature. 
attack"], made with pencil on paper, on which there was a grid to facilitate the transfer of drawing to the appropriate painting support ${ }^{15}$. Cezary Jellenta wrote about this painting while reporting on one of his visits in the artist's studio during completion of this monumental work. The image was then found at the drawing stage made with charcoal on a support, accompanied by an oil sketch, painted on a separate, smaller support. According to the report, both paintings were to have a lot of impact on the spectator ${ }^{16}$. Moreover, there were also minute painting sketches, which proceeded the appropriate composition. These are the sketch depicting two young children, made for the painting called Krowy na łace ["Cows on the grass"] (fig. 1) and the sketch of the painting entitled Myśliwi w sitowiu ["Hunters in the bulrush"], depicting a hunter (fig. 2-3), and the sketch Cietrzewie na toku ['Black grouses' lek"], which was a preliminary study of the birds for the painting entitled $\mathrm{Na}$ polowaniu ["Hunting"] (fig. 4-5). All the aforementioned works were made with pencil on paper. They are not elaborate drawing studies, whose form is to be reflected in the support. They are more like sketch notes, a sensational study of a character or movement. This manner of painting refers to the rules, which Wojciech Gerson instilled in his students and at whose studio Kowalski started his artistic career. Gerson believed that the best model to copy is nature and encouraged his trainees to study it carefully and persistently. It seems that Wierusz-Kowalski eagerly approved of the encouragement to study the world on the regular basis. It is visible in his sketches as well as in the sketchbook retained in the National Museum in Cracow. The sketchbook is full of tiny notes made by the artist, which prove his skilful drawing workshop, cautious sense of observation and his talent in terms of composition ${ }^{17}$. The aforementioned methods of work of the artist performing his painting studies and sketches, which were distinctive preliminary stages before the actual paintings as well as making use of the photographs and props, are close to artistic methods of other artists, who received their education at the Academy ${ }^{18}$.

15 The drawing $(28 \times 47 \mathrm{~cm})$, ca. 1885 , belongs to the Regional Museum in Suwałki.

16 Cezary Jellenta, Galeria ostatnich dni: wizerunki, zbiory, pomysły (Kraków: L. Zwoliński i Sp., 1897), 40-41. See Cezary Jellenta, „Ze wspomnień 'Nowoateńskich' ”, Prawda 37 (1889): 441-442. 14.IX.1889.

17 Ptaszyńska, Alfred Wierusz-Kowalski, 221-223, 231 and indicated literature.

18 The example may by artistic workshop of Józef Brandt. The artist often used photography as a sort of equivalent for a sketch proceeding the actual painting, in which an artist gains interesting themes or conducts compositional analysis of particular scenes. Moreover, Brandt 


\section{Role of painting sketches}

According to the rules of academism, preliminary sketches should be deprived of details and half-tones. Paints were spread with brave streaks which simplified the form. Thick paint was applied with a flat bristle brush. Such technique, embedding the character of an artist's "painting scripture", became more and more popular at the end of the nineteenth century ${ }^{19}$. It seems that painted sketches were the favourite form of expression of Wierusz-Kowalski, who employed them not only in the adjuvant elaborations, but also in self-sufficient paintings, which constitute a great part of his artistic output. Wierusz-Kowalski left a wide range of sketched landscape themes or images of the animals (e.g. Domy na łakach ["Houses in the meadows"], fig. 6; Portret dziewczyny ["Portrait of a girl"], fig. 7; Ranny Tatar padajacy z koniem ["Wounded Tatar falling down with a horse"], fig. 8; Dwa wilki ["Two wolves"], fig. 9), in which his personality was entirely expressed. It appears that it was not the purpose of the artist to precise the form or colour; and the analysis of the technique suggests that they were spontaneously made, sensual notes of the nature. Such works added up to a certain new value in the artistic activity of A. Wierusz-Kowalski, which escaped the rules of academism. He made this kind of sketches probably out of typically artistic reasons, which proves that he was a sensitive and reflective observer of the world. Wierusz-Kowalski then used the themes, which he frequently applied in the finished works, e.g. the images of wolves, so often appearing in his paintings (fig. 9) ${ }^{20}$. In terms of the composition and technique, there must

performed additional drawing and painting sketches and used props, which he collected in his studio. Mariusz Klarecki, ,Józef Brandt: fotografia w malarstwie, malarstwo w fotografii”, in Ateny nad Izara, 269-283 and indicated literature. Compare also the analysis of Aleksander Gierymski's workshop and specification of the artist's techniques conducted by Ewa Doleżyńska, "Materiały malarskie i technika w obrazach olejnych Aleksandra Gierymskiego" (PhD thesis, Nicolaus Copernicus University, 2006), 26-30 and indicated literature.

19 It is indicated in the literature that in the particular period artists more often paid attention to the technical aspects of the paintings. This tendency in art was to be promoted by the Munich Academy and the class supervised by K. Piloty. Ekkehard Mai, „Maltechnik an deutschen Kunstakademien im 19. Jahrhundert”, in Das 19. Jahrhundert und die Restaurierung, Beiträge zur Malerei, Maltechnik und Konservierung, ed. Heinz Althöfer (München: Callwey, 1987), 33.

20 According to the report of the artist's granddaughter, Barbara Nasierowska, in Mikorzyn, the estate of the family of Wierusz-Kowalski, there were built special pens and closures for the wolves. Barbara Nasierowska, „Wspomnienia rodzinne”, in O Alfredzie Wieruszu-Kowalskim, 21. Moreover, it is indicated in the literature that the artist from a very young age was close to nature, observing the animals and analyzing the changes of the natural phenomena. It is also known that he was a devoted hunter. All this certainly added up to his sense of ob- 
be highlighted the painting entitled Sanna ["Sleigh ride"] (fig. 10), whose main topic is casually, yet expressively employed winter landscape with a road covered with snow, not the people travelling in the sleigh themselves. Wierusz-Kowalski every so often returned to this kind of image. However, more often he placed the sleigh, horses and people in the foreground. The abovementioned paintings are the examples of sketches; yet, they have certain features typical of completed artworks. The border between an adjuvant sketch and accomplished painting with all the constituents referring to the new artistic tendencies, became clearly obliterated.

\section{Artistic expression}

While examining complete and detailed paintings, we are able to notice the impastos and brave strokes of the brush, which come from the bottom layers of the picture and not always are connected with the elements presented in the painting itself, which is clearly visible in the picture Zakochani ["In love"] (fig. 11-12). It can be assumed that these are the tracks of the academic stage of the underpainting type. Still, this stage presupposed certain texture only in the light parts and as such it was ultimately limited by the polishing of the painting surface ${ }^{21}$. In several works by Wierusz-Kowalski the textures of the bottom layer are visible in the lights, shadows and half-tones. One may have a feeling that the preliminary work was a vigorous painting sketch. The result of such manner was painting surface with clearly marked brushwork performed with thick paintbrushes (also flat ones).

Under conditions of academism, this kind of painting was close to preliminary sketches performed on different, smaller format; or a sort of academic underpainting in the portraits. The latter type was always painted on the target material and carefully polished before the actual painting's completion. In the works discussed in here, the lower brushwork was always covered by

servation, which contributed to the authenticity of the image of nature, which he presented in his works. The artist's son reported that young Wierusz-Kowalski was not indifferent to the surrounding landscapes. Even during a couple day long journey from his homeplace to Kalisz, at that time sixteen-year-old boy passionately sketched resting horses, carts, stagecoaches and inns seen on the way. Thus, it is visible that the tendency to embedding the surrounding world in form of the drawing notes had been rooted in the artist even before he found himself in the studio of W. Gerson. Janina Zielińska, „Rodzime motywy w twórczości Alfreda Wierusza-Kowalskiego", in O Alfredzie Wieruszu-Kowalskim, 59-60, 62-63.

21 Polishing of the underpainting layer was obligatory according to the painting procedures established in the French Academy. Boime, The Academy, 37-39 and indicated literature. 
the artist with the painting study with many realistic details. It was also more carefully performed. Thus, some artworks of Wierusz-Kowalski, there appears a combination of an expressive and texture oil sketch and precise painting elaboration, accurate from the perspective of academic rules as well as expectations of the middle-class customers. It may prove the temperament of the artist and his inner fight between new trends and traditional tendencies in art, and conservative demands of the purchasers of his paintings.

Numerous paintings of Wierusz-Kowalski, which were performed at the end of his artistic career, are of particularly thrifty, sketchy nature. They were painted in other stylistics, the one that followed certain changes, which then took place in art. The instance are pictures Na polowaniu ["On the hunt”], Dziewczyna pod drzewami ["A girl under trees”], Dziewczyna w zieleni ["A girl in green”] or Jesienny pejzaż [“Autumn landscape”]. Here, the artist quit typical features of his manner, i.e. precise drawing, logical combination of colorful accords, pursuit of reflecting the mood and climate of the scene. His aim was to perform the paintings quickly and "carelessly" and modify the technique of operating the brush and spreading paint on the canvas ${ }^{22}$. In the same manner he performed the background, animals or figures. Then, he worked quickly with a broad colour patch and introduced vigorous touches of a painting tool, which reflected details of a painting in a schematic way. All the artist's attention was paid to the general expression of the painting, yet the lightness typical of such technique was still maintained. He used bristle brushes of different breadth, whose ducts were clearly seen in thick oil paint as well as under the painting spatula ${ }^{23}$. Those devices made it possible to

22 Ptaszyńska, Alfred Wierusz-Kowalski, 270-271.

23 Flat bristle paintbrushes gained popularity in the 19th century and their origin was connected to the new system of placing bristle in a metal aglet, easy to form. This kind of brushes were popular especially amongst French impressionists as they made it possible to obtain distinguished textural effects in comparison with round brushes. Alexander Katlan, „The American Artist's Tools and Materials for On-Site Oil Sketching”, Journal of the American Institute for Conservation 38, no. 1 (1999): 24-25 and indicated literature, Access $7^{\text {th }}$ of December, 2017, DOI: 10.2307/3179835. Painting spatulas were more often used by the artists in the 2 nc half of the $19^{\text {th }}$ century. In the literature from before 1880 , information of using this type of devices most frequently refers to grinding and mixing paint on the palette and then moving it to special containers, or transferring the paint on a greater painting supports, which were developed mostly with the paintbrushes. Leslie Carlyle, The Artist's Assistant. Oil Painting Instruction Manuals and Handbook in Britain 1800-1900 with Reference to Selected Eighteenth-Century Sources (London: Archetype Publications, 2001), 224-225 and indicated literature; Władysław Ślesiński, „Warsztat artysty malarza z pierwszej połowy XIX wieku", Ochrona Zabytków 22, no. 4 (1969): 262 and indicated literature. 
cover certain surface quickly with paint and obtain the effect of a texture. He operated with a paintbrush, spatula or consistency of a painting material in different manners and directions. Sometimes he used thick, juicy and short paint. Another time, he chose more liquid paint. Regardless of the technique, just like many other painters of Munich School, he employed brown underpainting to enrich the colours of his pictures. The examples of such approach are paintings Przed meczetem ["In front of the mosque"] or Postój powstańca [“Insurgent resting”] (fig. 13-16).

\section{Bibliography}

Basiul, Elżbieta, Magdalena Sitkiewicz. Jakie tajemnice kryją obrazy monachijczyków? Kilka nowych spostrzeżeń na temat warsztatu malarskiego Alfreda Wierusza-Kowalskiego. Report, academic session „Egzotyczna Europa. Malarstwo monachijskie 1870-1914”. Suwałki, 5-6th October, 2015.

Boime, Albert. The Academy and French Painting in the Nineteenth Century. London: Phaidon, 1971.

Buhler, Hans-Peter. Józef Brandt, Alfred Wierusz-Kowalski i inni. Polska szkoła monachijska. Translated by Tomasz Kozłowski. Warszawa: Amber, 1997.

Carlyle, Leslie. The Artist's Assistant. Oil Painting Instruction Manuals and Handbook in Britain 1800-1900 with Reference to Selected Eighteenth-century Sources. London: Archetype Publications, 2001.

Dajnowska, Anna. „Alfred Wierusz-Kowalski w świetle opinii polskiej krytyki artystycznej w latach 1870-1915”. In O Alfredzie Wieruszu-Kowalskim. Studia, szkice, wspomnienia. Materiały z sesji popularnonaukowej w 150-lecie urodzin Artysty. Suwałki, 11 października 1999 r., ed. Zbigniew Fałtynowicz and Zygmunt Filipowicz, 35-57. Suwałki: Stowarzyszenie Przyjaciół Suwalszczyzny, 2000.

Doleżyńska, Ewa. „Materiały malarskie i technika w obrazach olejnych Aleksandra Gierymskiego". Ph.D. thesis, Nicolaus Copernicus University in Torun, 2006.

Elliott, Virgil. Traditional Oil Painting. Advanced Techniques and Concepts from the Renaissance to the Present. New York: Watson-Guptill Publications, 2007.

Holeczko-Kiehl, Andrzej. „Wierni miłości do ojczyzny”. Artyści polscy w kręgu Monachium”. In Brandt... Malczewski... Siemiradzki...: polscy monachijczycy, malarze polscy w kręgu Akademii Sztuk Pięknych w Monachium 1828-1914. Wystawa malarstwa ze zbiorów Lwowskiej Galerii Sztuki we Lwowie, Katowice: Muzeum Śląskie, 2005-2006,

Holeczko-Kiehl, Andrzej. Introduction to Brandt... Malczewski... Siemiradzki...: polscy monachijczycy, malarze polscy w kręgu Akademii Sztuk Pięknych w Monachium 1828-1914. Wystawa malarstwa ze zbiorów Lwowskiej Galerii Sztuki we Lwowie, Katowice: Muzeum Śląskie w Katowicach, 2005-2006 
Jaroszyński, Tadeusz. „Obrazy Wagnera oraz jego uczni Polaków”. Tygodnik Ilustrowany 21 (1906): 408-409. 26.V.1906.

Jellenta, Cezary. Galeria ostatnich dni: wizerunki, zbiory, pomysły. Kraków: L. Zwoliński i Sp., 1897.

Jellenta, Cezary. „Ze wspomnień ‘Nowoateńskich””. Prawda 37 (1889): 441-442. 14.IX.1889.

Jooss, Birgit. „Akademia Sztuk Pięknych w Monachium”. In Malarze polscy w Monachium. Studia i szkice. Materiały z sesji naukowej, ed. Zbigniew Fałtynowicz and Eliza Ptaszyńska, 13-19. Suwałki: Muzeum Okręgowe, 2007.

Jooss, Birgit. „Między studium antyków a klasą mistrzowską. Codzienne zajęcia w monachijskiej akademii sztuki w XIX wieku”. Translated by Marcin Pastwa. In Ateny nad Izara. Malarstwo monachijskie. Studia i szkice, ed. Eliza Ptaszyńska, 17-37. Suwałki: Muzeum Okręgowe, 2012.

Katlan, Alexander. „The American Artist's Tools and Materials for On-Site Oil Sketching”. Journal of the American Institute for Conservation 38, no. 1 (1999): 21-32. Access $7^{\text {th }}$ of December, 2017. DOI: 10.2307/3179835.

Klarecki, Mariusz. „ózef Brandt: fotografia w malarstwie, malarstwo w fotografii”. In Ateny nad Izara. Malarstwo monachijskie. Studia i szkice, ed. Eliza Ptaszyńska, 269-283. Suwałki: Muzeum Okręgowe, 2012 .

Kleczyński, Jan. „Uczniowie Gersona”. In Wojciech Gerson i jego uczniowie. Przewodnik 65: lato 1931 roku. Towarzystwo Zachęty Sztuk Pięknych w Warszawie, 14-20. Warszawa: Druk M. Garasiński, 1931.

Mai, Ekkehard. „Maltechnik an deutschen Kunstakademien im 19. Jahrhundert”. In Das 19. Jahrhundert und die Restaurierung, Beiträge zur Malerei, Maltechnik und Konservierung, ed. Heinz Althöfer, 25-35. München: Callwey, 1987.

Nasierowska, Barbara. „Wspomnienia rodzinne”. In O Alfredzie Wieruszu-Kowalskim. Studia, szkice, wspomnienia. Materiały z sesji popularnonaukowej w 150-lecie urodzin Artysty. Suwałki, 11 października 1999, ed. Zbigniew Fałtynowicz and Zygmunt Filipowicz, 21-23. Suwałki: Stowarzyszenie Przyjaciół Suwalszczyzny, 2000. Poprzęcka, Maria. Akademizm. Warszawa: WAiF, 1980.

Ptaszyńska, Eliza. Alfred Wierusz-Kowalski 1849-1915. Warszawa: Wydawnictwo DiG, 2011.

Słupski, Feliks. „Wojciech Gerson. Artysta, nauczyciel, człowiek”. In Wojciech Gerson i jego uczniowie. Przewodnik 65: lato 1931 roku. Towarzystwo Zachęty Sztuk Pięknych w Warszawie, 5-13. Warszawa: Druk M. Garasiński, 1931.

Stępień, Halina. Artyści polscy w środowisku monachijskim 1856-1914. Warszawa: Instytut Sztuki PAN, 2003.

Ślesiński, Władysław. „O sytuacji w zakresie technologii i technik malarskich w dobie romantyzmu”. Ochrona Zabytków 19, no. 3 (1966): 13-22.

Ślesiński, Władysław. „Warsztat artysty malarza z pierwszej połowy XIX wieku”. Ochrona Zabytków 22, no. 4 (1969): 256-262. 
Techniki wielkich mistrzów malarstwa. Co-writers David A. Anfam, Mary Beal, Edwin Bowes, Anthea Callen, David Chandler, Judith Collins, Stephen Hackney, Clare Meredith, Jenny McCleery, Roy Perry, Caroline Villers, Nicholas Watkins, John Welchman. Translated by Dorota Stefańska-Szewczuk, Monika Dolińska, and Bożena Mierzejewska. Warszawa: Arkady, 2006.

Wankie, Władysław. „Aleksander Wagner i jego polscy uczniowie”. Świat 24 (1906): 11-12. 16.VI.1906.

Zielińska, Janina. „Rodzime motywy w twórczości Alfreda Wierusza-Kowalskiego”. In O Alfredzie Wieruszu-Kowalskim. Studia, szkice, wspomnienia. Materiały z sesji popularnonaukowej w 150-lecie urodzin Artysty. Suwałki, 11 października 1999, ed. Zbigniew Fałtynowicz, and Zygmunt Filipowicz, 59-65. Suwałki: Stowarzyszenie Przyjaciół Suwalszczyzny, 2000.

Ziemlewicz, Sylwia. Technika i technologia szkicu malarskiego Alfreda Wierusza-Kowalskiego pt. 'Przed burzą' pochodzącego z Muzeum Okręgowego w Suwałkach. M.A. thesis, Nicolaus Copernicus University in Toruń, 2013. 


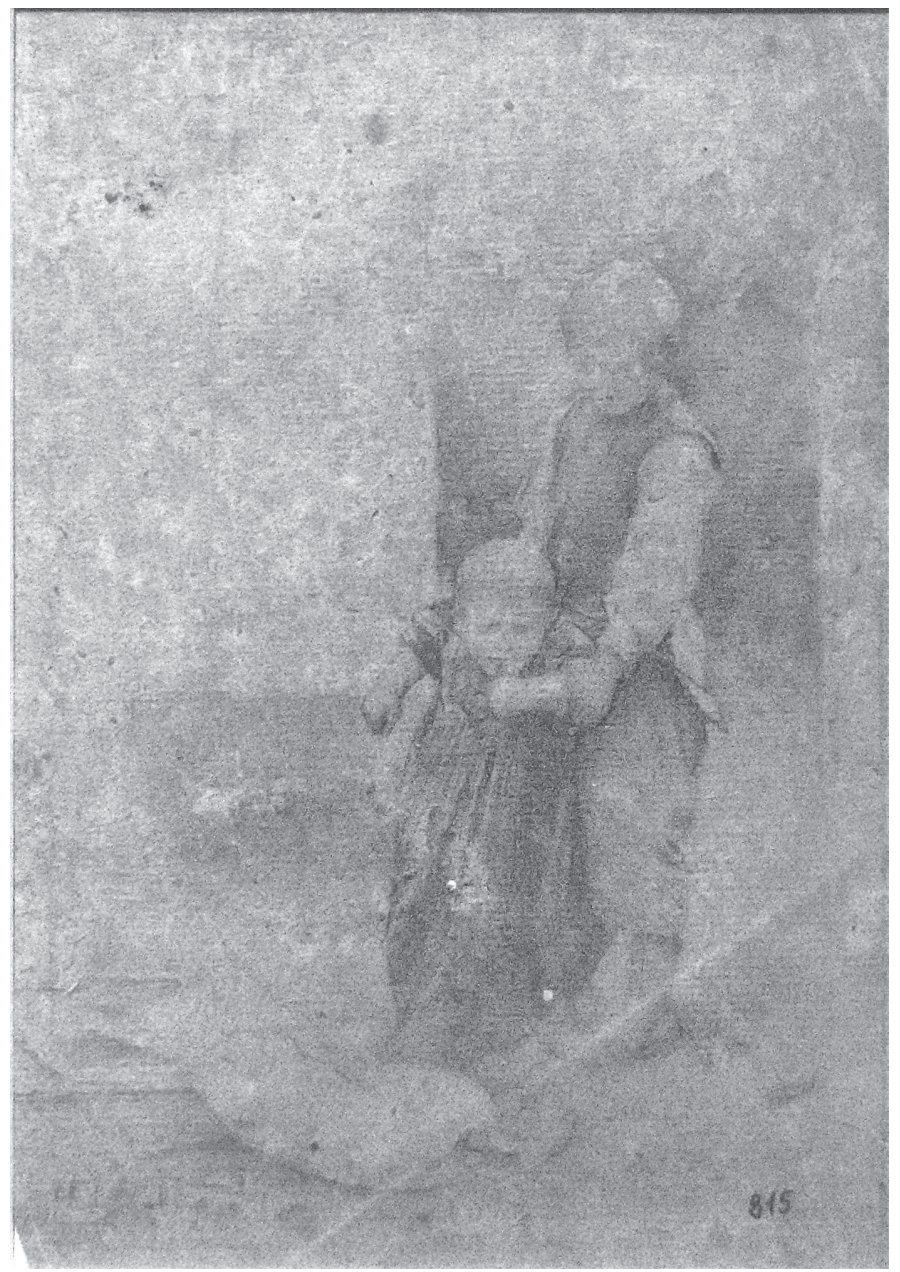

Fig. 1. Alfred Wierusz-Kowalski, Rodzeństwo [„Siblings”], ca. 1872, pencil on paper, 19 x 13,5 cm, Muzeum Okręgowe w Suwałkach [Regional Museum in Suwałki]. Black and white photography. Sketch of the painting Krowy na łace ["Cows on the grass"], undated, oil on canvas, $66,5 \times 93,5 \mathrm{~cm}$, private collection abroad, sold in Germany in 2006. Photo by Adam Cupa 


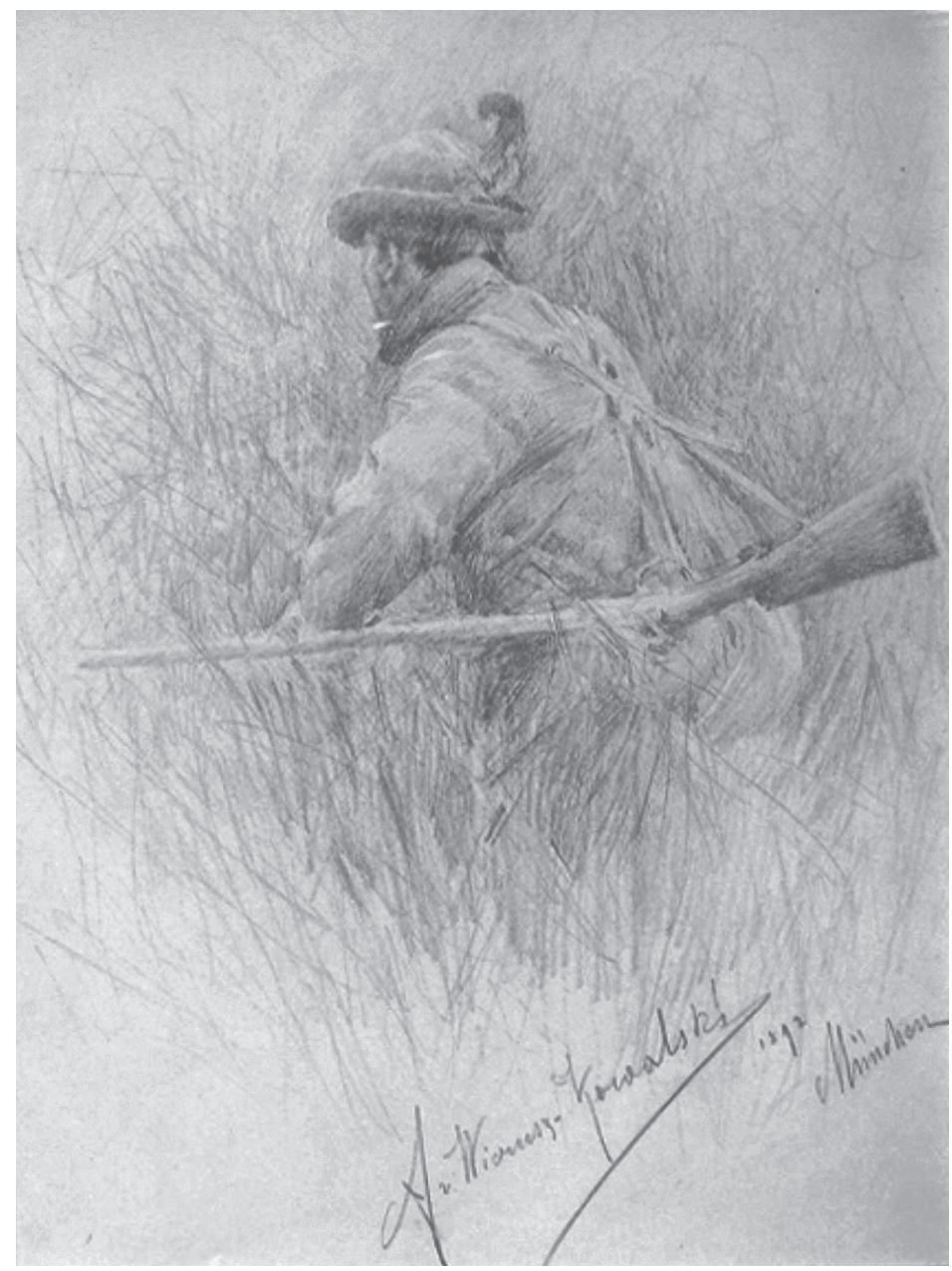

Fig. 2. Alfred Wierusz-Kowalski, Myśliwy [„Hunter”], 1892, pencil on paper, 24,8 x 18,7 cm, Muzeum Okręgowe w Suwałkach. Black and white photography. Photo by Adam Cupa 


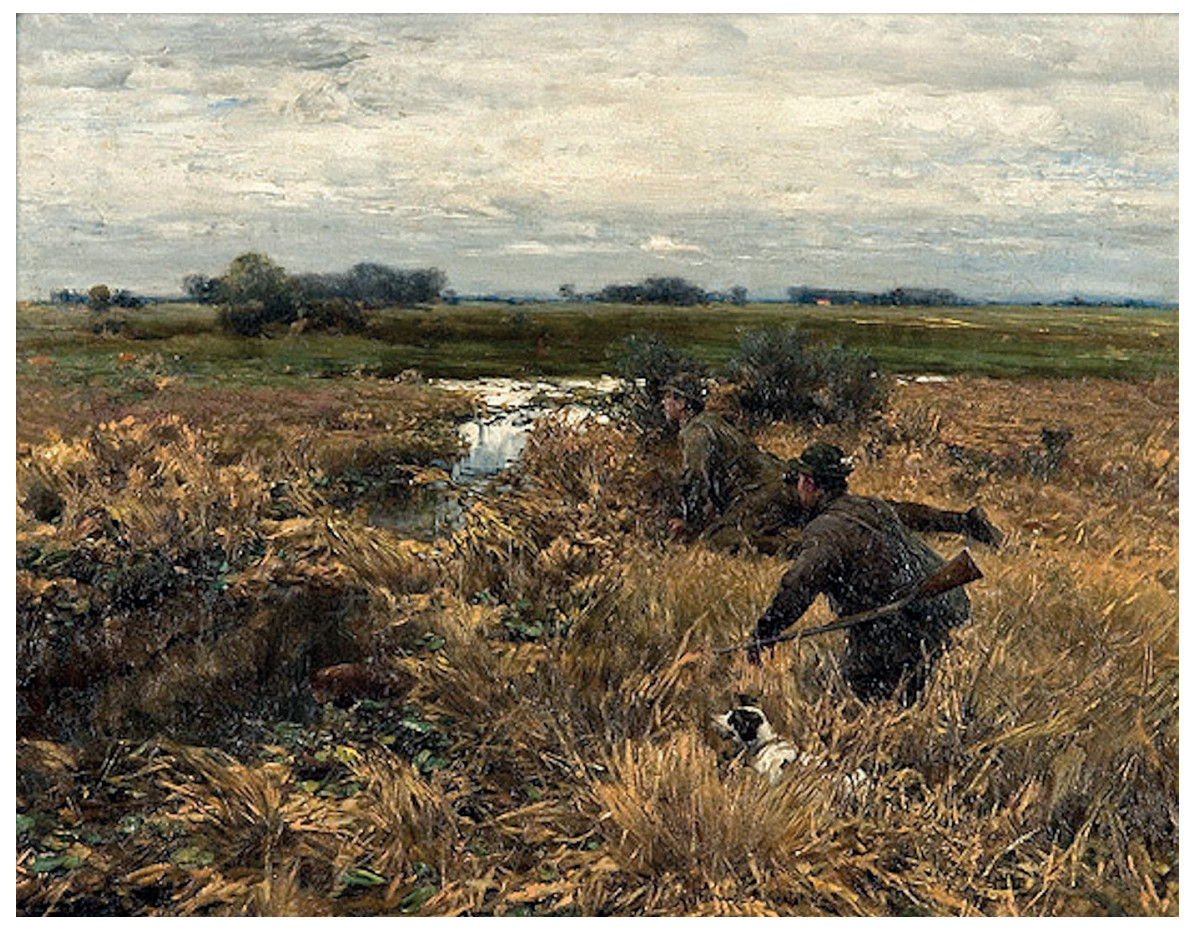

Fig. 3. Alfred Wierusz-Kowalski, Myśliwi w sitowiu ["Hunters in the bulrush"], after 1892, oil on canvas, $44,5 \times 56,5 \mathrm{~cm}$, private collection. Photo by Adam Cupa 


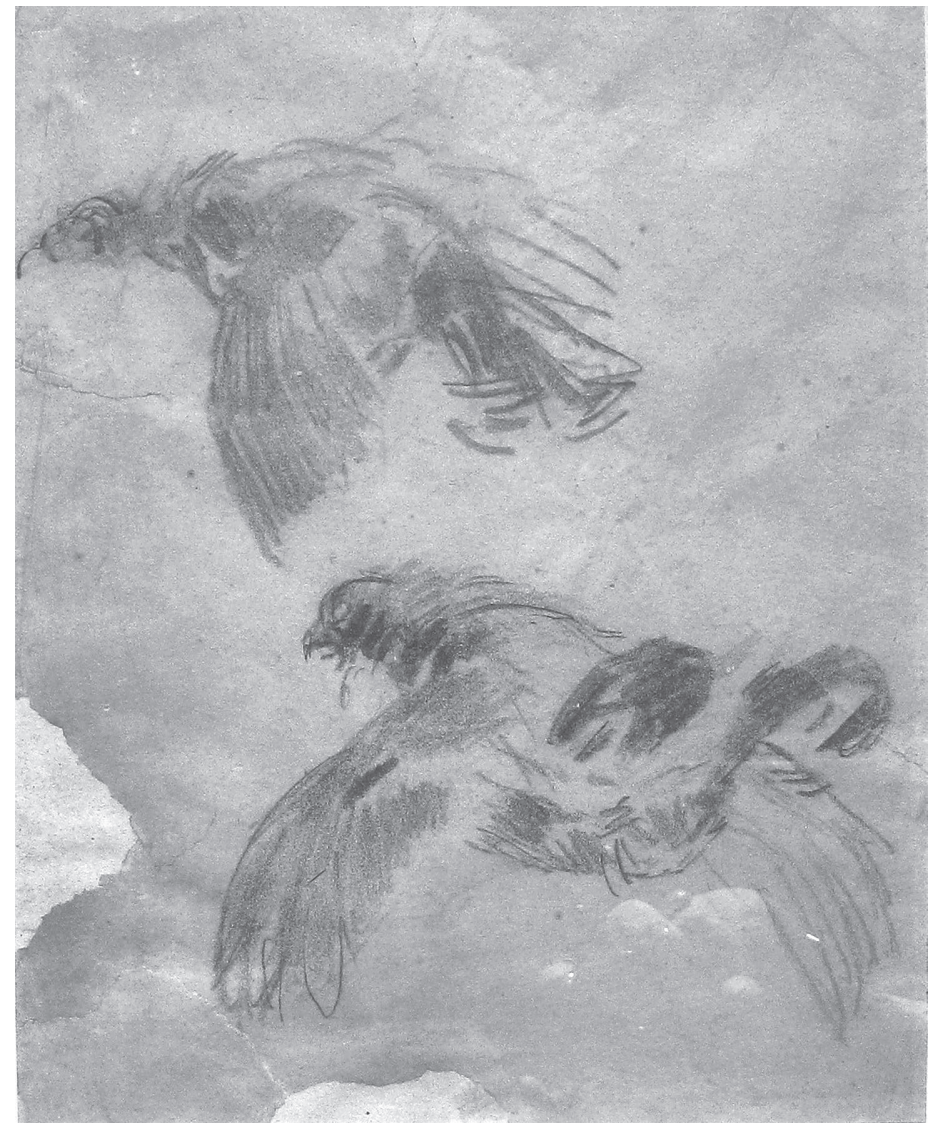

Fig. 4. Alfred Wierusz-Kowalski, Cietrzewie na toku [„Black grouses’ lek”], ca. 1880 , pencil on paper, 31 x 21,5 cm, Muzeum Okręgowe w Suwałkach. Black and white photo. Sketches of the painting called Na polowaniu ["Hunting"]. Photo by Adam Cupa 


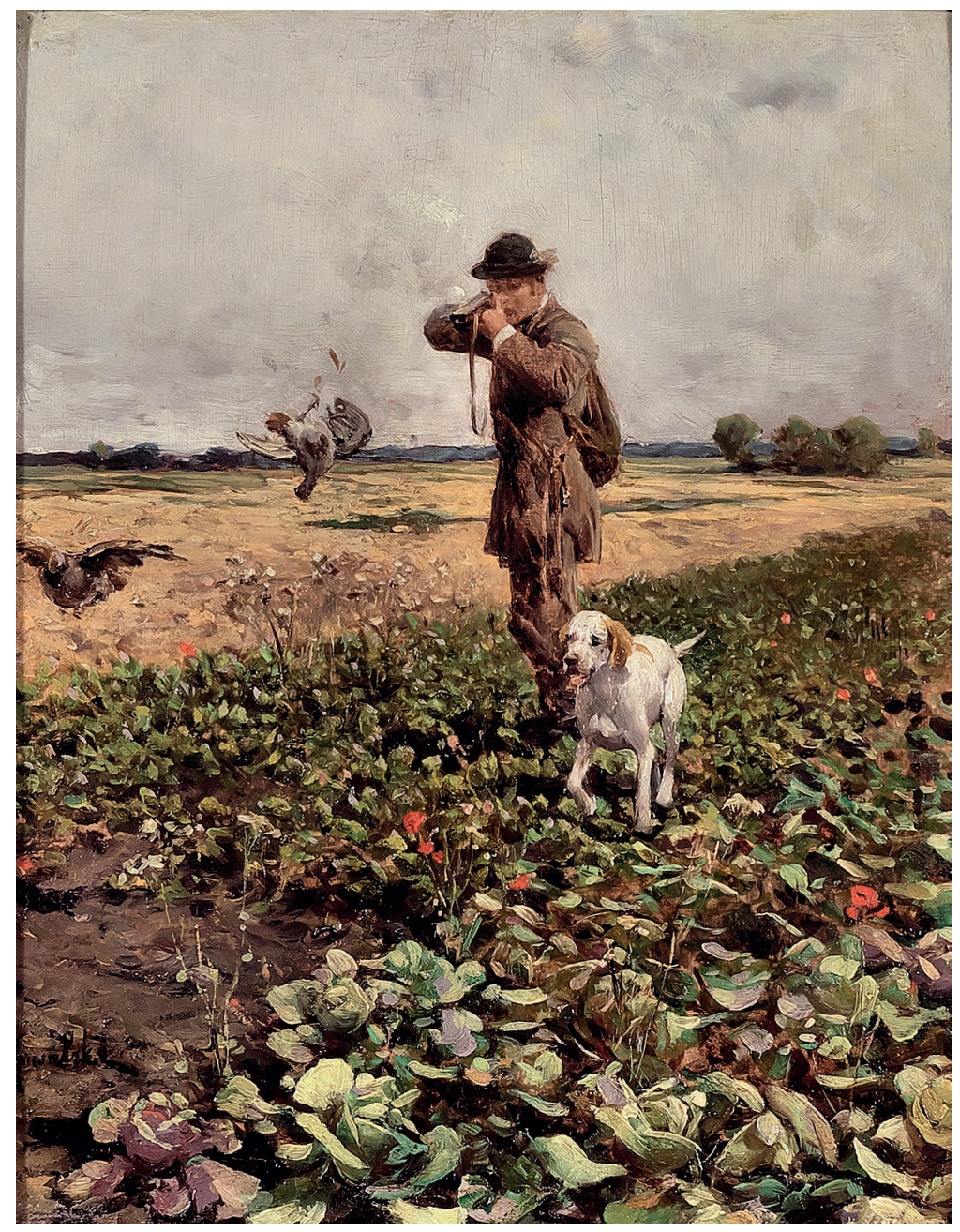

Fig. 5. Alfred Wierusz-Kowalski, Na polowaniu [„Hunting”], ca. 1880, oil on panel, 28 x $22 \mathrm{~cm}$, Muzeum Okręgowe w Suwałkach. Photo by Adam Cupa 


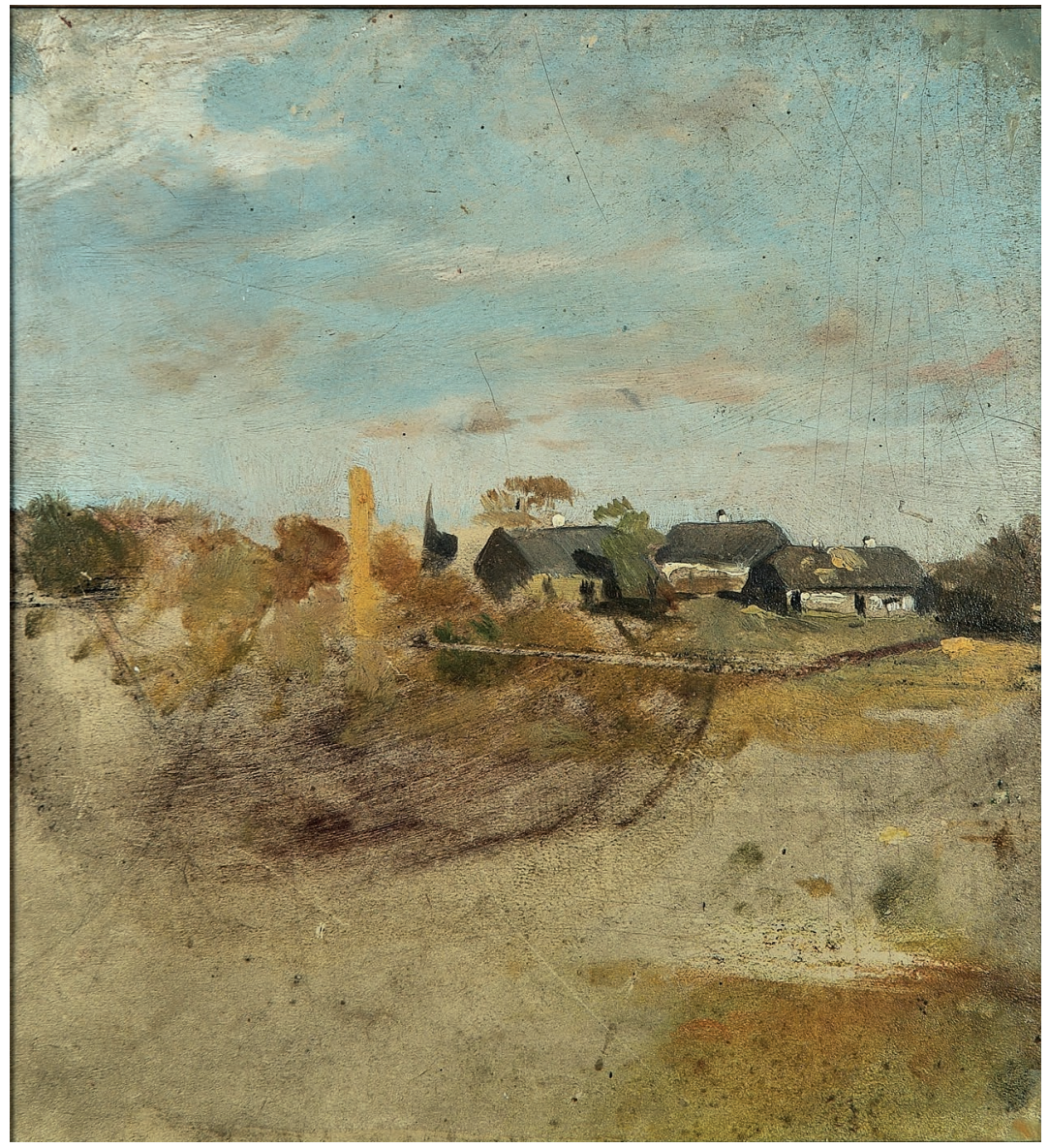

Fig. 6. Alfred Wierusz-Kowalski, Domy na łąkach [„Houses in the Meadows”], ca. 1880, oil on board, 18 x 16 cm, Muzeum Okręgowe w Suwałkach. Photo by Adam Cupa 


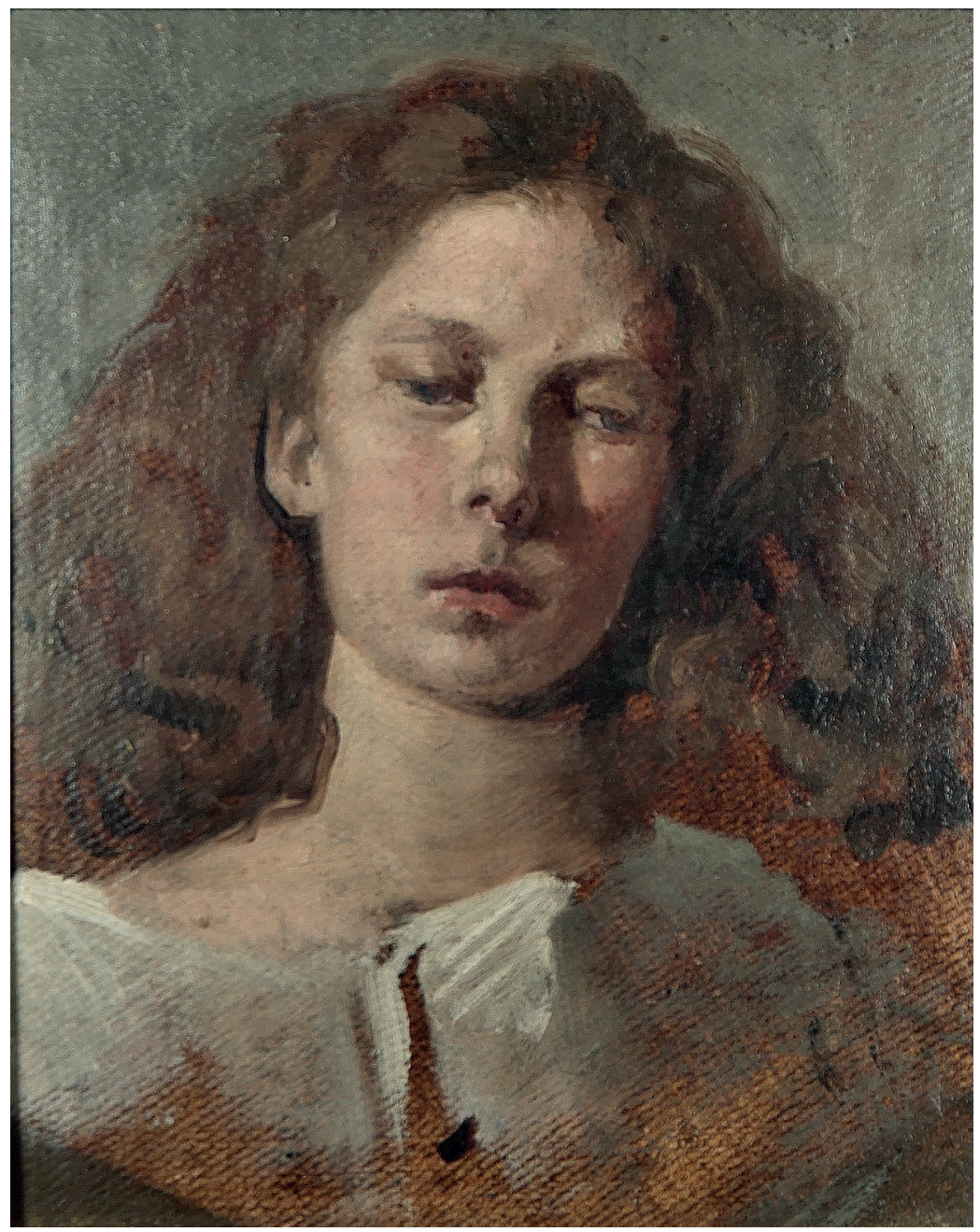

Fig. 7. Alfred Wierusz-Kowalski, Portret dziewczyny [„Portrait of a girl”], ca. 1880, oil on canvas, 18 x 15,5 cm, Muzeum Okręgowe w Suwałkach. Photo by Adam Cupa 


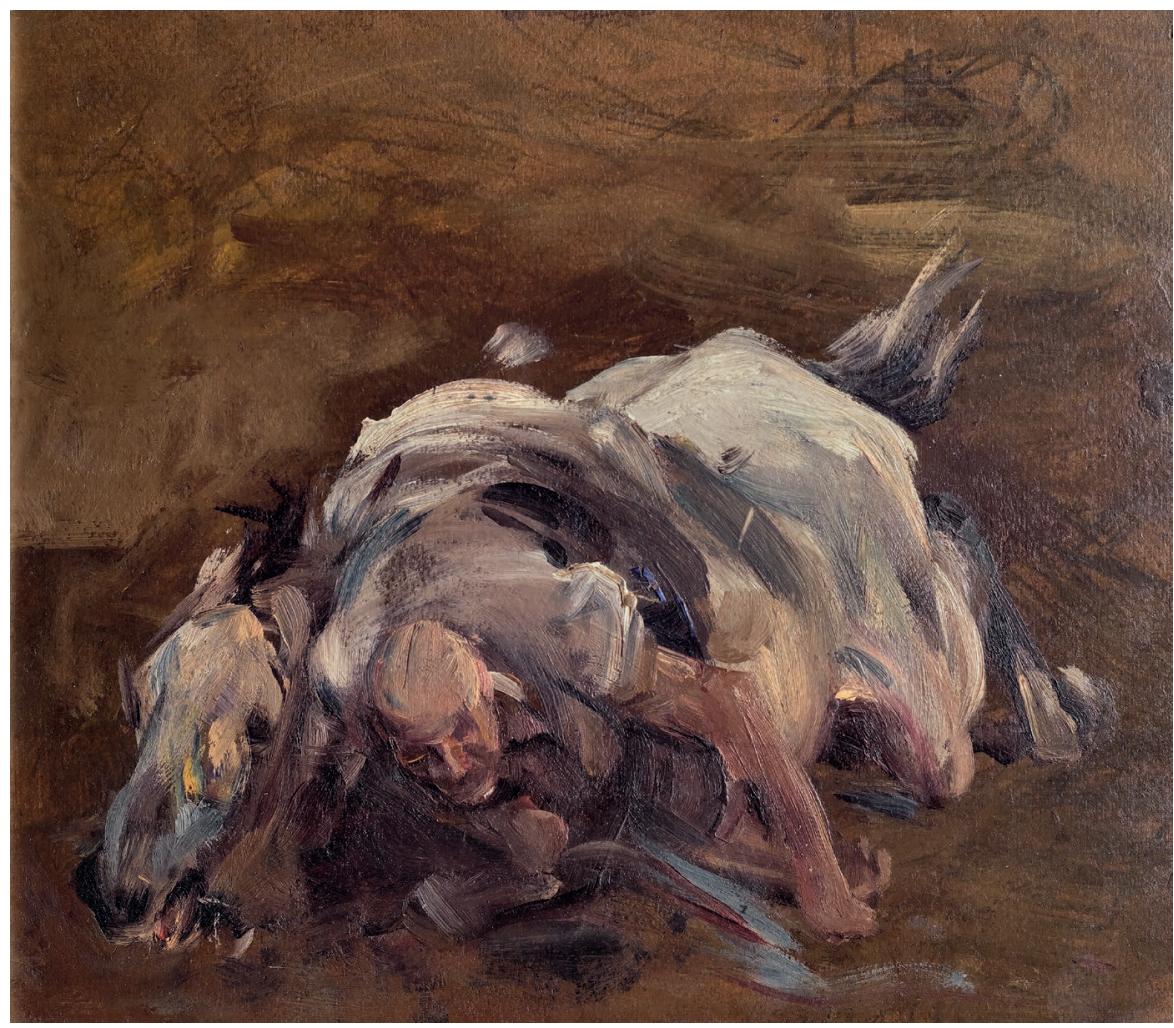

Fig. 8. Alfred Wierusz-Kowalski, Ranny Tatar padający z koniem [„Wounded Tatar falling down with a horse"], ca. 1910, oil on cardboard, 27 x 32 cm, Muzeum Okręgowe w Suwałkach. Photo by Adam Cupa 


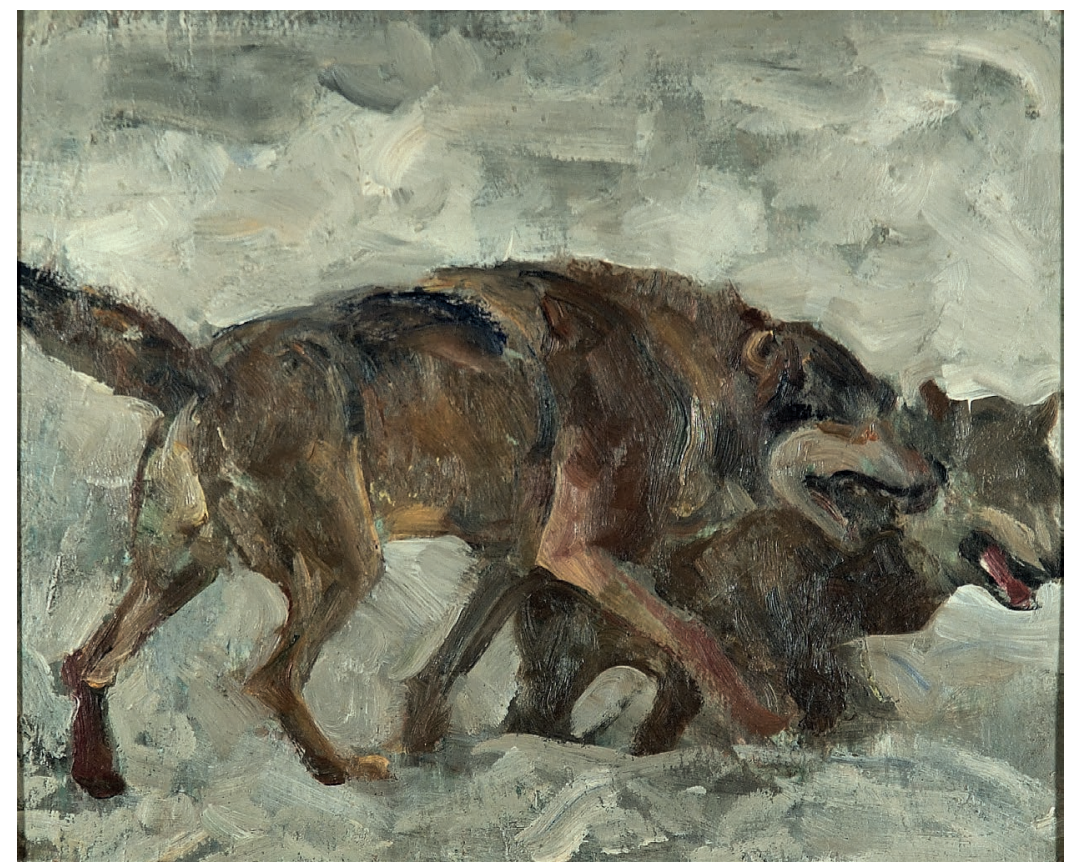

Fig. 9. Alfred Wierusz-Kowalski, Dwa wilki [„Two wolves”], ca. 1910, oil on cardboard, 25 x $31 \mathrm{~cm}$, Muzeum Okręgowe w Suwałkach. Photo by Adam Cupa

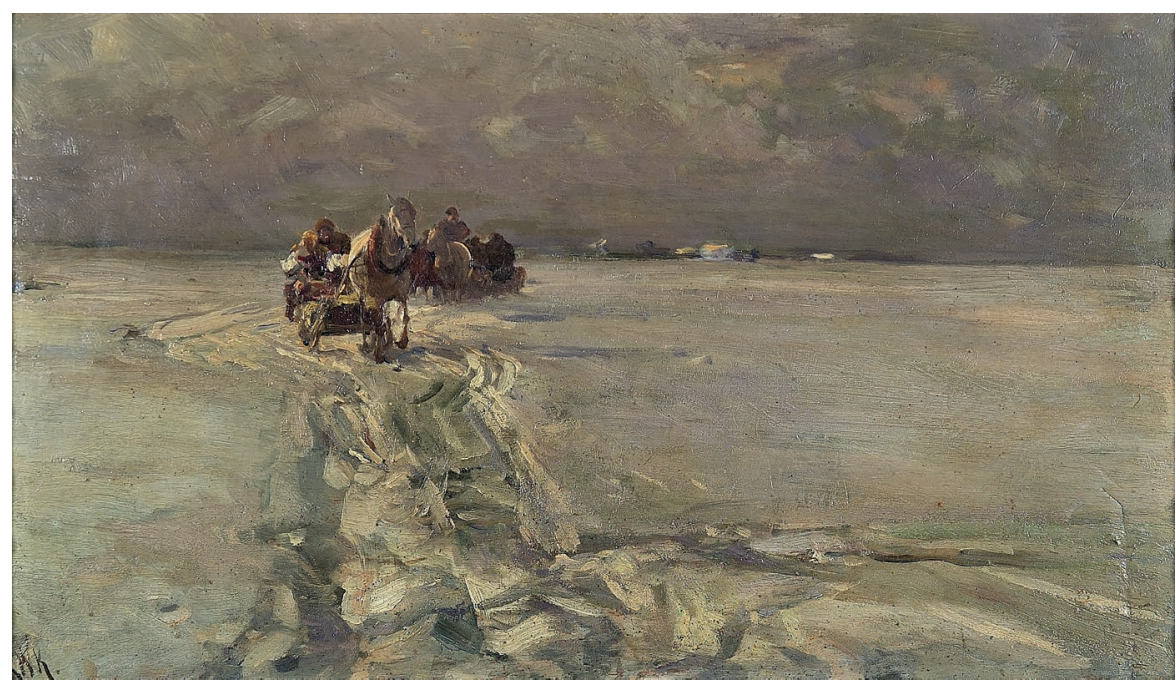

Fig. 10. Alfred Wierusz-Kowalski, Sanna [„Sleigh ride”], ca. 1890-1900, oil on panel, 28 x 48 cm, Muzeum Okręgowe w Suwałkach. Photo by Adam Cupa 


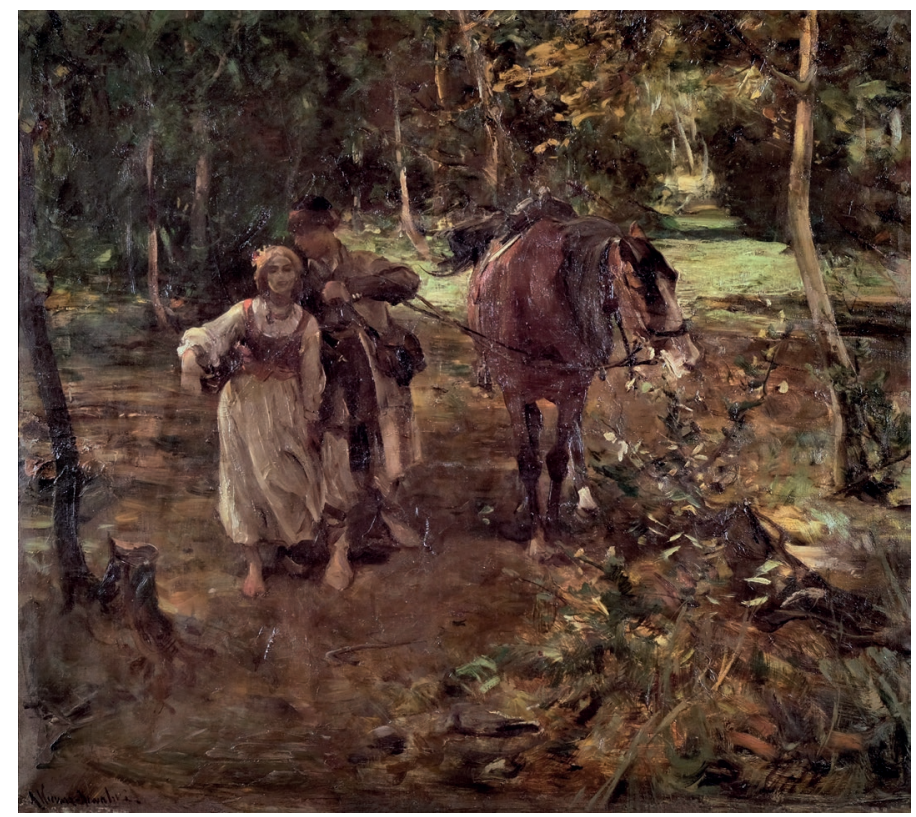

Fig. 11. Alfred Wierusz-Kowalski, Zakochani [„In love”], undated, oil on canvas, 81,5 x 91,5 cm, fragment, Muzeum Sztuki w Łodzi [Museum of Art in Łódź]. Photo by Adam Cupa

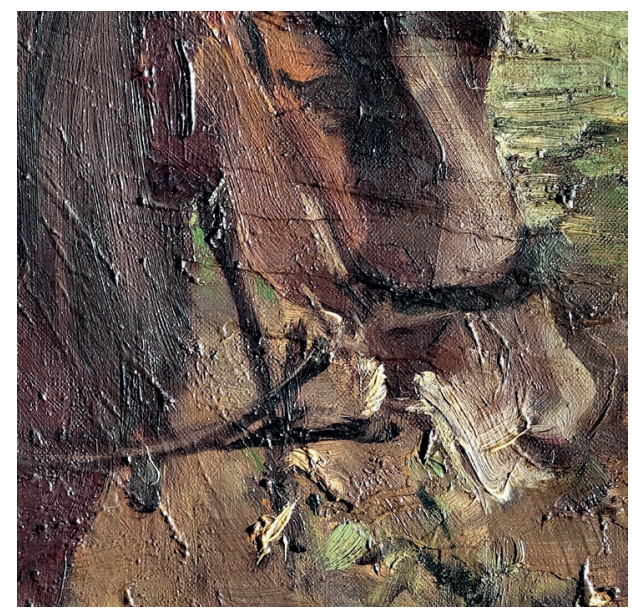

Fig. 12. Alfred Wierusz-Kowalski, Zakochani [,In love”], undated, oil on canvas, 81,5 x 91,5 cm, fragment, Muzeum Sztuki w Łodzi. Noticeable textural study of the preliminary painting work, whose sketch does not overlap the final composition of the painting. Photo by Adam Cupa 


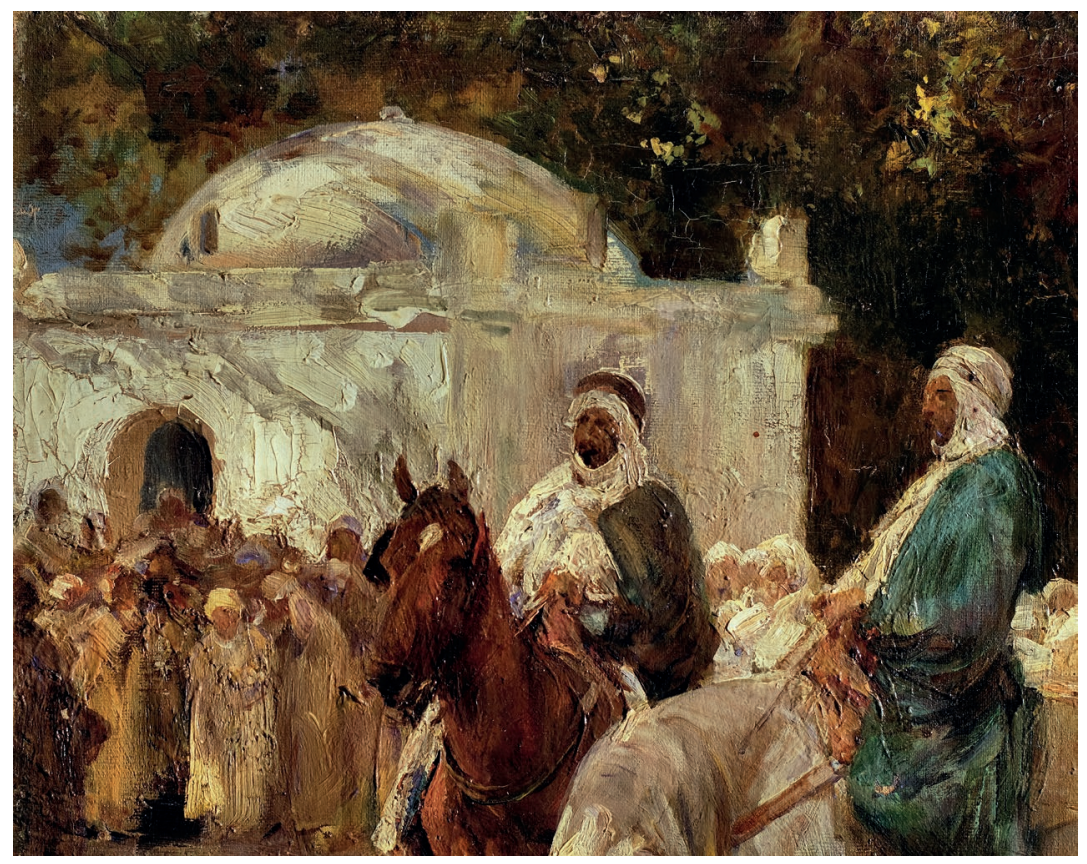

Fig. 13. Alfred Wierusz-Kowalski, Przed meczetem [“In front of the mosque”], after 1903, oil on canvas, $47 \times 62 \mathrm{~cm}$, private property, fragment. Photo by Adam Cupa

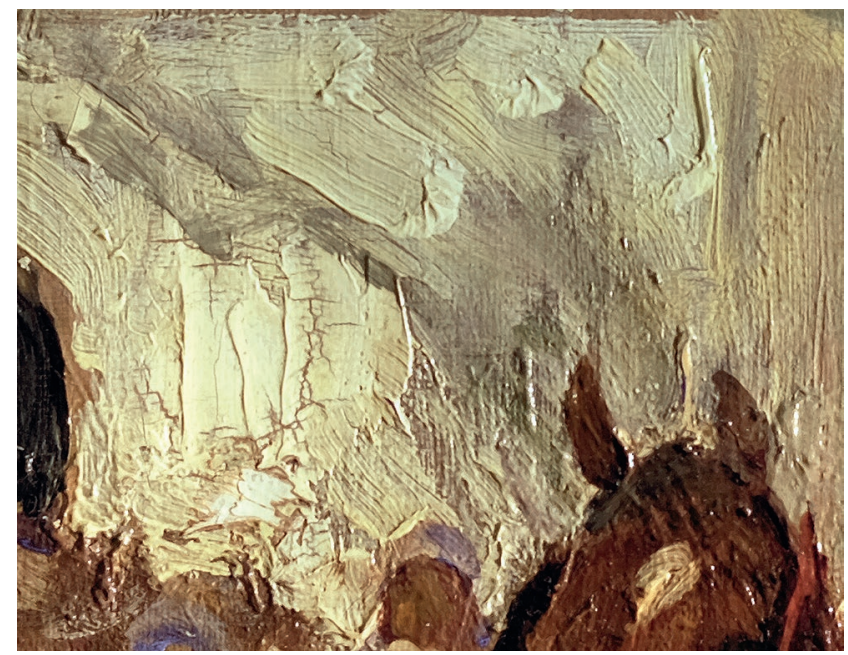

Fig. 14. Alfred Wierusz-Kowalski, Przed meczetem ["In front of the mosque"], after 1903, oil on canvas, 47 x $62 \mathrm{~cm}$, private property, fragment. Visible paint texture typical of a flat bristle brush and painting spatula. Photo by Adam Cupa 


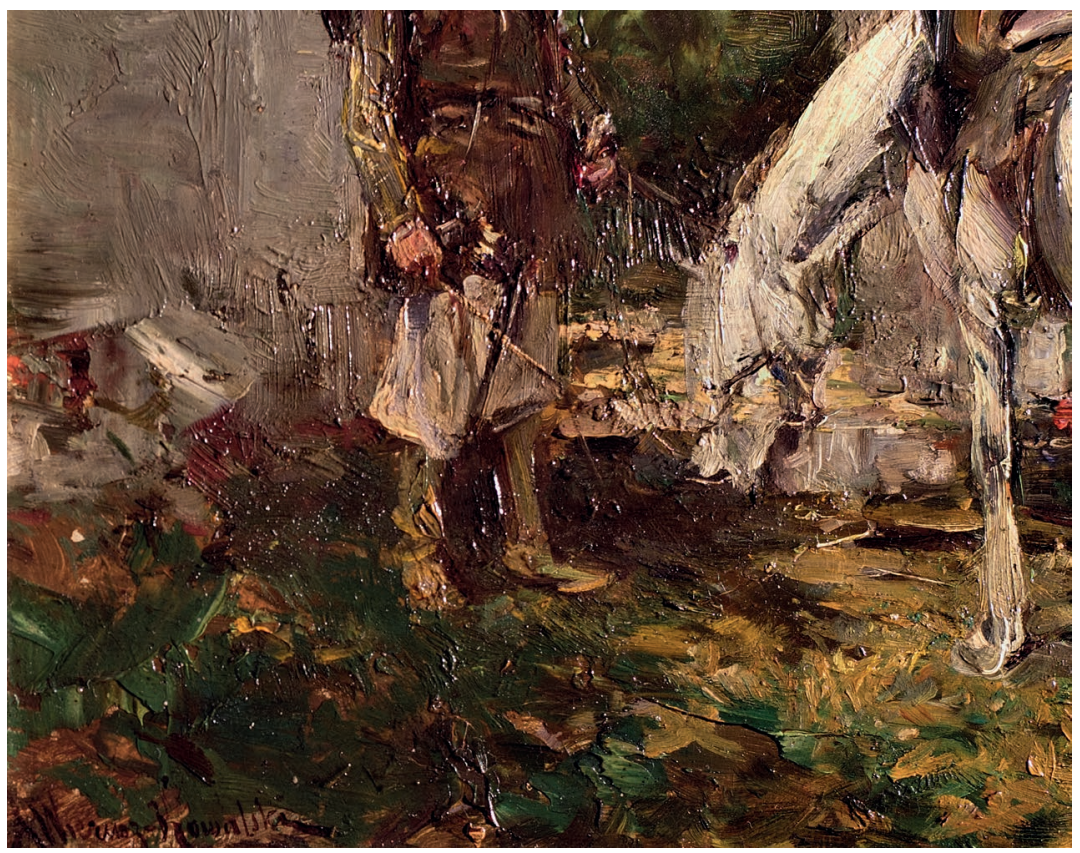

Fig. 15. Alfred Wierusz-Kowalski, Postój powstańca [“Insurgent resting”], ca. 1892-1895, oil on panel, $20 \times 35 \mathrm{~cm}$, fragment, Muzeum Okręgowe w Suwałkach, a gift of the artist's family. Noticeable brown underpainting in the preliminary study as well as distinguished work with a brush and spatula. Photo by Adam Cupa

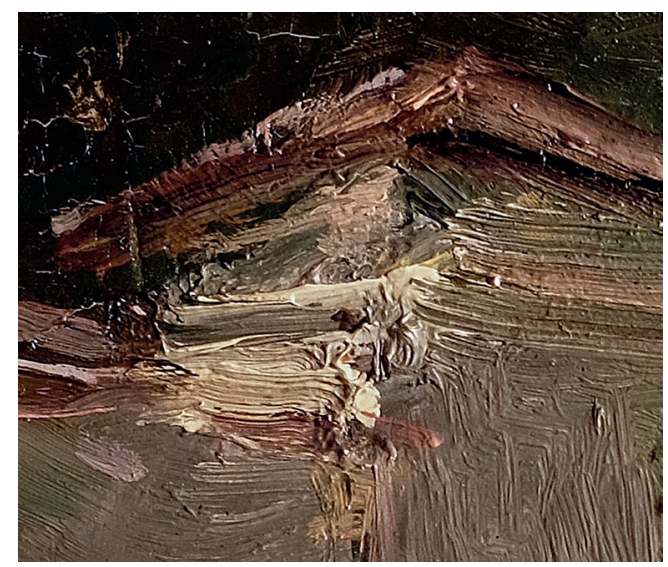

Fig. 16. Alfred Wierusz-Kowalski, Postój powstańca [„Insurgent resting”], ca. 1892-1895, oil on panel, $20 \times 35 \mathrm{~cm}$, fragment, Muzeum Okręgowe w Suwałkach, a gift of the artist's family. Noticeable brown underpainting in the preliminary study. Visible paint texture typical of a bristle brush. Photo by Adam Cupa 
